\title{
Penyelesaian Konflik Antar Umat Beragama (Studi Pada Komnas HAM Perwakilan Sumatera Barat)
}

\author{
Laurensius Arliman S.*
}

\begin{abstract}
Abstrak
Hak Asasi Manusia merupakan hak dasar yang melekat di dalam sanubari manusia itu sendiri yang tidak dapat dikurangi baik oleh masyarakat, pemerintah, maupun dirinya. Salah satunya adalah hak kebebasan beragama. Hak kebebasan beragama merupakan suatu hak yang bebas dipilih oleh seseorang. Komisi Nasional Hak Asasi Manusia merupakan lembaga mandiri yang kedudukannya setingkat dengan lembaga negara lainnya yang berfungsi melaksanakan pengkajian, penelitian, penyuluhan, pemantauan, dan mediasi HAM. Dari penelitian yang telah dilakukan, terlihat bahwa tidak ada koordinasi peranan antara Komnas HAM dengan pemerintah. Komnas HAM sebagai lembaga mandiri yang berfungsi menegakkan hak kebebasan beragama, tidak memiliki sikap tegas dalam mengimplementasikan peranannya. Dalam penelitian ini juga dikemukakan kasus penyelesaian konflik antar umat beragama, yaitu Peraturan Gubernur Sumatera Barat Nomor 17 Tahun 2011 tentang Larangan Kegiatan Jemaat Ahmadyah Indonesia di Provinsi Sumatera Barat dan Surat Keputusan Bersama Dua Menteri terkait dengan rumah ibadah, dimana Komnas HAM kurang memiliki sikap terhadap hal ini. Seharusnya, Komnas HAM sebagai lembaga mandiri memiliki sikap tegas dalam pelaksanaan fungsinya tersebut dan memiliki peraturan perundang-undangan tersendiri tentang peranan Komnas HAM.
\end{abstract}

Kata Kunci: konflik antar umat, kebebasan beragama, Komnas HAM, Ahmadyah, pelanggaran HAM.

\section{Inter-Religious Conflict Resolution}

\begin{abstract}
Human Rights is a human or fundamental rights inherent in the human heart itself, which can not be reduced either by the public, government and himself. One of them is the right to religious freedom. Right to religious freedom is a right that is freely chosen by the individual. The National Commission on Human Rights, an independent institution whose position is equal to other state agencies, which function to carry out an assessment, research, extension, monitoring, and mediation of human rights. From research findings, it appears that there is no coordination between Komnas HAM and government. Komnas HAM, as an independent institution whose function is to uphold the right of religious freedom, does not

PADJADJARAN Jurnal IImu Hukum Volume 2 Nomor 2 Tahun 2015 [ISSN 2460-1543] [e-ISSN 2442-9325]

* Dosen Sekolah Tinggi Ilmu Hukum Padang, Jalan A.R. Hakim Nomor 6 Padang, laurensiusarliman@gmail.com, S.H., M.Kn. (Universitas Andalas).
\end{abstract}


have a firm stance in implementing its role. This study also found cases of inter-religious conflict resolution, namely West Sumatra Governor Regulation No. 17 of 2011 on the Prohibition of the Activity of Ahmadyah Indonesia in West Sumatra province and two ministerial decree related to houses of worship, the Commission lacks the attitude towards it. Supposedly, Komnas HAM as an independent institution has a firm stance in the execution of these functions and has its own legislation on the role of the Komnas HAM.

Keyword: inter-religious conflict, freedom of religion, Komnas HAM, Ahmadyah, human rights violation.

\section{A. Pendahuluan}

Negara Republik Indonesia sebagai negara hukum sangat mengakui dan menjunjung tinggi Hak Asasi Manusia (HAM) dan kebebasan dasar manusia yang harus dilindungi dan harus dihormati demi peningkatan martabat kemanusiaan, kesejahteraan, dan kecerdasan serta keadilan. Pada masa Orde Baru, banyak terjadi pelanggaran HAM di berbagai daerah. Sejak tahun 1965 sampai sekarang telah tercatat berbagai penderitaan, kesengsaraan, dan kesenjangan sosial yang disebabkan oleh perilaku tidak adil dan diskriminatif. ${ }^{1}$ Perilaku ini merupakan pelanggaran HAM baik yang bersifat vertikal (dilakukan oleh negara terhadap warga negara) maupun horizontal (dilakukan antar warga negara), bahkan sebagian pelanggaran HAM tersebut masuk dalam kategori pelanggaran HAM berat (gross violation of human rights). ${ }^{2}$

Hukum di Indonesia menempatkan kebebasan beragama pada tatanan tertinggi. Kebebasan beragama dalam kacamata HAM sendiri mempunyai posisi yang kompleks. Amanat hak kebebasan beragama terdapat dalam Mukadimah Konstitusi Indonesia yang termasuk dalam Pembukaan Undang-Undang Dasar 1945 (UUD 1945). Amanat kebebasan beragama tersebut bahkan lahir sebelum Universal Declaration of Human Rights 1948 atau Deklarasi Universal Hak Asasi Manusia (DUHAM 1948). Hal ini menunjukkan bahwa pendiri republik ini menghormati dan menjunjung tinggi kebebasan beragama atas martabat kodrati manusia yang paling hakiki.

1 Eddie Riyadi (et.al.), Kebenaran Versus Keadilan, Jakarta: Elsam, 2003, hlm. 3.

2 Istilah Pelanggaran HAM berat (Gross Violation on Human Rights) yang menjadi bagian dari hukum positif nasional sejak diundangkannya Undang-undang Nomor 26 Tahun 2000 tentang Pengadilan HAM, pada tanggal 23 November 2000, memang tidak mendefinisikan pengertian istilah "pelanggaran HAM berat", melainkan menyebutkan kategori kejahatan yang merupakan pelanggaran HAM berat, yakni kejahatan genosida dan kejahatan terhadap kemanusiaan (Pasal 1 angka 2 junto Pasal 7 beserta penjelasannya dan juncto Pasal 9 beserta penjelasannya); sebagaimana dalam Laurensius Arliman S., Komnas HAM dan Perlindungan Anak Pelaku Tindak Pidana, Yogyakarta: Deepublish, 2015, hlm. 3. 
Sejatinya, hak atas kebebasan beragama dan berkeyakinan adalah hak untuk memilih, memeluk dan menjalankan agama dan keyakinan. Hak ini tidak dapat dikurangi dalam keadaan apapun (non-derogable rights) ${ }^{3}$ karena merupakan landasan bagi kebebasan manusia demi keadilan dan perdamaian. Lebih lanjut, konsep ini merupakan hak-hak yang tidak dapat ditangguhkan atau dibatasi (dikurangi) pemenuhannya oleh negara, meskipun dalam kondisi darurat sekalipun. Mengabaikan dan memandang rendah HAM telah mengakibatkan tindakantindakan yang melanggar hukum dan keji, serta melanggar norma-norma agama manapun yang diyakini. Hal tersebut membuat HAM harus dilindungi dengan peraturan hukum agar masyarakat tidak terpaksa melakukan pemberontakan sebagai usaha terakhir guna menentang tirani dan penindasan. Jaminan terhadap hak atas kebebasan beragama dan berkeyakinan terdapat pada instrumen HAM internasional dan peraturan perundang-undangan nasional.

Meskipun UUD 1945 telah mengalami beberapa kali amandemen, akan tetapi makna dari kebebasan beragama yang tertuang di dalam Pasal 29 UUD 1945 tidak pernah mengalami perubahan. Pada hakikatnya ketentuan Pasal 29 UUD 1945 sama dengan amanat Pasal 18 DUHAM 1948 yang menentukan:

"Setiap orang berhak atas kebebasan berpikir, berkeyakinan, dan beragama, hal ini mencakup kebebasan untuk berganti agama atau kepercayaannya, dan kebebasan untuk menjalankan agama atau kepercayaannya dalam kegiatan pengajaran, beribadah dan pentaatan, baik sendiri maupun bersama-sama dengan pihak lain, baik secara terbuka maupun pribadi." 4

Pemerintah Indonesia berkali-kali mengambil prakarsa untuk menumbuhkan toleransi di antara pemeluk agama, diantaranya adalah pada tahun 1967 telah diadakan Musyawarah Antar Umat Beragama yang diharapkan dapat melahirkan gentlement agreement di antara para tokoh dan pemimpin agama dalam memelihara kerukunan hidup. Pada Komentar Umum No. 22 dinyatakan bahwa:

"Hak atas berpikir, berkeyakinan, dan beragama (yang termasuk kebebasan untuk menganut kepercayaan) dalam pasal 18 bersifat luas dan mendalam;

3 Pasal 28 I ayat (1) menyatakan sebagai berikut: “Hak untuk hidup, hak untuk tidak disiksa, hak kemerdekaan pikiran dan hati nurani, hak beragama, hak untuk tidak diperbudak, hak untuk diakui sebagai pribadi di hadapan hukum, dan hak untuk tidak dituntut atas dasar hukum yang berlaku surut adalah hak asasi manusia yang tidak dapat dikurangi dalam keadaan apa pun". Hal ini merupakan salah satu dari konsep non-derogable rights. Selain itu hal ini kembali ditegaskan dalam pasal 4 UU HAM yang menyebutkan: "Hak untuk hidup, hak untuk tidak disiksa, hak kebebasan pribadi, pikiran dan hati nurani, hak beragama, hak untuk tidak diperbudak, hak untuk diakui sebagai pribadi dan persamaan di hadapan hukum, dan hak untuk tidak dituntut atas dasar hukum yang berlaku surut adalah hak asasi manusia yang tidak dapat dikurangi dalam keadaan apapun dan oleh siapapun".

4 Deklarasi Universal Hak Asasi Manusia Perserikatan Bangsa-Bangsa 1948 (DUHAM 1948). 
hak ini mencakup kebebasan berpikir mengenai segala hal, kepercayaan pribadi, dan komitmen terhadap agama atau kepercayaan, baik yang dilakukan secara individual maupun bersama-sama dengan orang lain." 5

Dengan demikian, hak atas kebebasan beragama dan berkeyakinan pada dasarnya meliputi dua dimensi individual dan kolektif. Dimensi individual tercermin dalam perlindungan terhadap keberadaan spiritual seseorang (forum internum) termasuk di dalam dimensi ini adalah memilih-mengganti, mengadopsi dan memeluk agama dan keyakinan. Sedangkan dimensi kolektif tercermin dalam perlindungan terhadap keberadaan seseorang untuk mengeluarkan keberadaan spiritualnya dan mempertahankannya di depan publik (forum eksternum). Dengan kata lain, pada Pasal 18 DUHAM 1948 dibedakan antara kebebasan berkeyakinan dan beragama atau berkepercayaan dari kebebasan untuk menjalankan agama atau kepercayaannya. Pembedaan ini secara legal sangat penting untuk membedakan di wilayah mana negara diperbolehkan untuk membatasi dan wilayah mana negara dilarang untuk melakukan pembatasan.

Demi undang-undang tersebut dapat terealisasi secara nyata, maka segenap pihak harus berupaya untuk mendukung mewujudkan pemenuhan hak tersebut. Negara sebagai pemangku kewajiban HAM setidaknya memiliki tiga kewajiban yang harus dilaksanakan untuk menjamin hak atas kebebasan beragama dan berkeyakinan terpenuhi, yaitu: kewajiban untuk menghormati (to respect); melindungi (to protect); dan memenuhi (to fullfil). ${ }^{6}$ Negara dalam hal ini adalah pemerintah yang sebagai penyelenggara negara harus bertindak cepat, tepat, dan tegas bila mengetahui ada pihak-pihak tertentu yang menodai hak atas kebebasan beragama dan berkeyakinan. Era demokratisasi telah menghadirkan kebebasan luar biasa yang memungkinkan kita untuk mengembangkan berbagai potensi dasar kemanusiaan dan peradaban. Ditambah dengan kondisi di tengah kemajemukan moral yang makin menguat seiring dengan globalnya dunia kita. ${ }^{7}$ Namun demikian, di samping kemajuan yang sangat berarti itu, kini kita juga tengah menghadapi masalah-masalah baru yang cukup fundamentalis.

Pembentukan institusi nasional HAM seharusnya lembaga yang efektif dan mempunyai kelayakan untuk disebut sebagai sebuah institusi nasional. Untuk itu, pembentukan institusi nasional HAM harus memenuhi elemen-elemen yang diatur di dalam standar internasional. Pembentukan institusi nasional HAM sebagaimana disebutkan di dalam Prinsip-Prinsip Paris 1991 atau Paris Principle 1991. Upaya

5 Pasal 18 Komentar Umum oleh Komite Hak Asasi Manusia PBB (Komite HAM PBB) berkaitan dengan Kovenan Hak Sipil dan Politik Nomor 22 yang menyangkut tentang makna dalam DUHAM 1948.

6 Suryadi Radjab, Indonesia: Hilangnya Rasa Aman. Hak Asasi Manusia dan Transisi Politik Indonesia, Jakarta: Perhimpunan Bantuan Hukum dan Asasi Manuisa Indonesia dan The Asia Foundation, 2002, hlm 6.

7 Erick J. Barus, Kebebasan Beragama, HAM dan Komitmen Kebangsaan, Jakarta: Bidang Marturia-PGI, 2009, hlm. 13. 
perlindungan kebebasan beragama di Indonesia berdasarkan prinsip Bhineka Tunggal Ika, yaitu kesatupaduan dan pengakuan atas kondisi keberagaman. Demi memastikan adanya jaminan perlindungan, kemajuan, penegakan dan pemenuhan HAM, maka kehadiran institusi nasional HAM sangatlah diperlukan untuk dibangun demi kemajuan dan perlindungan HAM. Ketetapan Majelis Permusyawaratan Rakyat (Tap MPR) Nomor XVII/MPR/1998 yang merupakan salah satu landasan lahirnya Undang-Undang Nomor 39 Tahun 1999 tentang Hak Asasi Manusia (UU HAM) menyatakan, lembaga-lembaga tinggi negara dan seluruh aparatur pemerintah untuk menghormati, menegakkan dan menyebarluaskan pemahaman mengenai HAM kepada seluruh masyarakat. Selain itu juga disebutkan bahwa pelaksanaan penyuluhan, pengkajian, pemantauan, penelitian dan mediasi tentang hak asasi manusia dilakukan oleh suatu Komisi Nasional Hak Asasi Manusia (Komnas HAM) yang ditetapkan dengan undang-undang. ${ }^{8}$ UU HAM disahkan pada tanggal 23 September 1999 untuk menunjukkan konsistensi tegaknya kebebasan beragama sebagai tindak lanjut dari amanat Tap MPR tersebut. Dalam undang-undang tersebut, selain mengatur mengenai HAM juga mengatur mengenai kelembagaan Komnas HAM. Komnas HAM sebagaimana disebutkan di dalam Pasal 1 angka 7 UU HAM adalah: "Lembaga mandiri yang kedudukannya setingkat dengan lembaga negara lainnya, yang berfungsi melaksanakan pengkajian, penelitian, penyuluhan, pemantauan, dan mediasi hak asasi manusia."

Timbulnya berbagai konflik agama yang terjadi belakangan ini, sangat merongrong kebebasan beragama. Beberapa contoh konflik terjadi didaerah seperti: Sungai Rumbai Kabupaten Dhamasraya (1995), Padang (Pertengahan 19961997), Padang (2004-2005), Solok dan Pesisir Selatan (Pertengahan 2005), Pasar Usang Kabupaten Padang Pariaman (2007), dan Pasaman (2009). ${ }^{9}$ Masih banyak konflik tentang kebebasan beragama yang terjadi, padahal undang-undang sendiri sudah menegaskan perlindungan terhadap kebebasan beragama tersebut dan telah membentuk suatu lembaga independen di Indonesia yang memiliki fungsi sebagaimana yang tertuang dalam UU HAM.

Berdasarkan Keputusan Presiden Nomor 50 Tahun 1993 tentang pembentukan Komnas HAM (Keppres Komnas HAM 1993), Komnas HAM bertujuan: pertama, membantu pengembangan kondisi yang kondusif bagi pelaksanaan HAM sesuai dengan Pancasila, UUD 1945, PBB serta DUHAM; kedua, meningkatkan perlindungan HAM guna mendukung terwujudnya pembangunan manusia nasional, yaitu pembangunan manusia Indonesia seutuhnya maupun

8 Komite Nasional Hak Asasi Manusia (KOMNAS HAM), Laporan Tahunan Komisi Nasional Hak Asasi Manusia Indonesia, Jakarta: Komnas HAM, 2004, hIm. 3.

9 Sudarto, "Kebebasan Agama Dalam Cita Dan Realita”, Makalah Hasil Pemantauan Sekaligus Pengalaman Langsung Dari Lembaga PUSAKA Padang, disampaikan di Padang, 2011. 
pembangunan masyarakat pada umumnya. ${ }^{10}$ Komnas HAM diberi mandat sebagai satu-satunya institusi yang mempunyai kewenangan untuk melakukan penyelidikan pelanggaran HAM yang berat. Pada penyelesaian konflik antar umat beragama, Komnas HAM memiliki fungsi yang sangat penting dalam membantu penyelesaian pelanggaran HAM. Wewenang ini lebih diperkuat lagi dengan disahkannya UndangUndang Nomor 26 Tahun 2000 tentang Pengadilan Hak Asasi Manusia (UU Pengadilan HAM). Berbagai usaha pemerintah dilakukan dengan membentuk Komnas HAM beserta aturannya dalam UU HAM, namun berbagai konflik seperti yang telah disebutkan dalam uraian di atas tetap terjadi.

\section{B. Peranan Komnas HAM dalam Penyelesaian Konflik Antar Umat Beragama}

Setiap orang mempunyai hak untuk menikmati kehidupannya serta tumbuh dan berkembang dalam berbagai kehidupannya yang aman, tenteram, damai, dan sejahtera. Oleh karena itu, manusia sebagai ciptaan Tuhan Yang Maha Esa dikaruniai seperangkat hak yang melekat kepadanya yang wajib dihormati, dijunjung tinggi dan dilindungi oleh negara, hukum, pemerintah, dan setiap orang demi penghormatan dan perlindungan harkat dan martabatnya sebagai seorang manusia.

Konsep peranan memiliki sejarah yang panjang baik dalam ilmu antropologi, sosiologi, maupun psikologi. Dalam rumusan klasiknya, Linton membedakan peranan dengan status. Status mengacu kepada posisi atau kedudukan di dalam sebuah sistem sosial sementara, sedangkan peranan mengacu kepada aspek perilaku yang berasosiasi atau berhubungan dengan status yang diberikan. ${ }^{11}$

Tujuan peranan dari seseorang didasari oleh peraturan yang sah, seperti peraturan administratif, kode etik, dan lain-lain. Dikarenakan tidak adanya persetujuan dalam harapan peranan ini, Gross Mason dan Mc Eachern mengemukakan bahwa anggota peranan sendirilah yang menentukan ukuran kebijaksanaan terhadap pemberhentian sebuah kewenangan peranan yang mereka miliki. Banyaknya jumlah dan jenis kebijaksanaan yang dijalankan oleh seseorang anggota peranan dalam sebuah sistem yang legal merupakan bagian dari fungsi orientasi atau sikapnya terhadap harapan dari peranan itu sendiri. Perilaku peranan masing-masing berbeda dengan orientasi peranan dan harapan peranan, meliputi tindakan yang memiliki maksud yang jelas pada pengambilan kebijakan/keputusan. $^{12}$

\footnotetext{
10 Keputusan Presiden Nomor 50 Tahun 1993 tentang Pembentukan Komnas HAM.

11 Kumanto Sunarto, Pengantar Sosiologi, Jakarta: Fakultas Ekonomi Universitas Indonesia, 1993, hlm. 73.

12 William M. Evans, The Sociology Of Law A Social-Structrural Perspective, Free Press, A Division of Macwiliam Publishing, New York: University of Pennsylvania, hlm. 241-243.
} 
Sejalan dengan pengertian tersebut, Soerjono Soekanto mengemukakan bahwa, "peranan (role) adalah aspek yang dinamis dari kedudukan (status)". Apabila seseorang melaksanakan hak dan kewajiban sesuai dengan kedudukannya, maka dia menjalankan suatu peranan. ${ }^{13}$ Selanjutnya, peranan lebih menunjuk pada fungsi yang dilaksanakan. Linton menjelaskan bahwa suatu peranan ialah 'the dynamic aspect of a status' (aspek dinamis dari status). Suatu status ialah 'a collection of rights and duties' (atau kumpulan hak dan kewajiban). Seseorang menjalankan hak dan kewajiban yang merupakan statusnya.

Secara sosiologis Komnas HAM Indonesia mempunyai kedudukan (status) dan peranan (role). Kedudukan sosial merupakan posisi tertentu di dalam struktur masyarakat yang mungkin tinggi, sedang-sedang saja, atau rendah. Kedudukan tersebut sebenarnya merupakan wadah yang isinya adalah hak dan kewajiban tertentu yang merupakan peranan (role). Oleh karena itu, seseorang yang mempunyai kedudukan tertentu lazimnya dinamakan pemegang peranan (role occupant). Suatu hak merupakan wewenang untuk berbuat atau tidak berbuat, sedangkan kewajiban adalah beban dan tugas. Peranan adalah dinamisasi dari fungsi yang melekat pada seseorang atau suatu badan. Dalam hal ini, Komnas HAM yang kedudukannya sebagai lembaga negara yang didalamnya terdapat hak-hak yang harus dilaksanakan. Adapun fungsi-fungsi tersebut adalah pemantauan, penyelidikan, pengkajian, dan mediasi.

Sejarah yang begitu panjang telah dilalui dalam pembentukan Komnas HAM dengan satu tujuan, yaitu demi kesejahteraan rakyat sebagaimana yang terdapat dalam UUD 1945 yang kita yakini sebagai konstitusi tertinggi bila dilihat dari segi hierarkinya. Memang pengaturan tentang Komnas HAM ini tidak diatur dalam undang-undang tersendiri namun dalam UU HAM dijelaskan secara terperinci tentang tujuan dan fungsi dari Komnas HAM itu sendiri.

Adapun tujuan lembaga ini dibentuk adalah: ${ }^{14}$

a. Mengembangkan kondisi yang kondusif bagi pelaksanaan HAM sesuai dengan Pancasila, UUD 1945, Piagam PBB, serta DUHAM 1948; dan

b. Meningkatkan perlindungan dan penegakan HAM guna berkembangnya pribadi manusia Indonesia seutuhnya dan kemampuannya berpartisipasi dalam berbagai bidang kehidupan.

Dengan telah ditingkatkannya dasar hukum pembentukan Komnas HAM dari keputusan presiden menjadi undang-undang dan tersebarnya perwakilan dan kantor Komnas HAM, diharapkan Komnas HAM dapat menjalankan fungsinya dengan lebih optimal untuk mengungkapkan berbagai bentuk pelanggaran HAM. Dengan undang-undang tersebut, Komnas HAM juga mempunyai subpoena power

\footnotetext{
13 Soerjono Soekanto, Sosiologi Suatu Pengantar, Jakarta: Raja Grafindo Persada, 2006, hlm. 212-217.

14 Pasal 75 Undang-Undang Nomor 39 Tahun 1999 tentang Hak Asasi Manusia (UU HAM).
} 
dalam membantu penyelesaian pelanggaran HAM. Komnas HAM bertugas dan berwenang melakukan: ${ }^{15}$

a. Pengkajian dan penelitian berbagai instrumen internasional HAM dengan tujuan memberikan saran-saran mengenai kemungkinan aksesi dan/atau ratifikasi;

b. Pengkajian dan penelitian berbagai peraturan perundang-undangan untuk memberikan rekomendasi mengenai pembentukan, perubahan dan pencabutan peraturan perundang-undangan yang berkaitan dengan HAM;

c. Penerbitan hasil pengkajian dan penelitian;

d. Studi kepustakaan, studi lapangan, dan studi banding di negara lain mengenai HAM;

e. Pembahasan berbagai masalah yang berkaitan dengan perlindungan, penegakan, dan pemajuan HAM; dan

f. Kerjasama pengkajian dan penelitian dengan organisasi, lembaga atau pihak lainnya, baik tingkat nasional, regional, maupun internasional dalam bidang HAM.

Dalam melaksanakan fungsi Komnas HAM dalam penyuluhan, Komnas HAM bertugas dan berwenang melakukan: ${ }^{16}$

a. Penyebarluasan wawasan mengenai HAM kepada masyarakat Indonesia;

b. Upaya peningkatan kesadaran masyarakat tentang HAM melalui lembaga pendidikan formal dan non-formal serta berbagai kalangan lainnya; dan

c. Kerjasama dengan organisasi, lembaga atau pihak lainnya, baik di tingkat nasional, regional, maupun internasional dalam bidang HAM.

Dalam melaksanakan fungsi Komnas HAM dalam pemantauan, Komnas HAM bertugas dan berwenang melakukan: ${ }^{17}$

a. Pengamatan pelaksanaan HAM dan penyusunan laporan hasil pengamatan tersebut;

b. Penyelidikan dan pemeriksaan terhadap peristiwa yang timbul dalam masyarakat berdasarkan sifat atau lingkupnya patut diduga terdapat pelanggaran HAM;

c. Pemanggilan kepada pihak pengadu atau korban maupun pihak yang diadukan untuk dimintai dan didengar keterangannya;

d. Pemanggilan saksi untuk diminta dan didengar kesaksiannya, dan kepada saksi pengadu diminta menyerahkan bukti yang diperlukan;

15 Berbagai data dan informasi yang berkenaan dengan Pedoman Internasional Pembentukan Institusi Nasional HAM (Paris Principle 1991), disarikan dari buku Institusi Nasional Hak Asasi Manusia, seri pelatihan profesional No. 4 yang diterbitkan oleh Perserikatan Bangsa-Bangsa.

16 Ibid.

17 Ibid. 
e. Peninjauan di tempat kejadian dan tempat lainnya yang dianggap perlu;

f. Pemanggilan terhadap pihak terkait untuk memberikan keterangan secara tertulis atau menyerahkan dokumen yang diperlukan sesuai dengan aslinya dengan persetujuan ketua pengadilan;

g. Pemeriksaan setempat terhadap rumah, pekarangan, bangunan, dan tempattempat lainnya yang diduduki atau dimiliki pihak tertentu dengan persetujuan ketua pengadilan; dan

h. Pemberian pendapat berdasarkan persetujuan ketua pengadilan terhadap perkara tertentu yang sedang dalam proses peradilan, bilamana dalam perkara tersebut terdapat pelanggaran HAM dalam masalah publik dan acara pemeriksaan oleh pengadilan yang kemudian pendapat Komnas HAM tersebut wajib diberitahukan oleh hakim kepada para pihak.

Selanjutnya dalam melaksanakan fungsi Komnas HAM dalam mediasi, Komnas HAM bertugas dan berwenang: ${ }^{18}$

a. Mengadakan perdamaian antar pihak-pihak yang bertikai;

b. Menyelesaikan perkara melalui konsultasi, negosiasi, mediasi, konsiliasi dan penilaian ahli;

c. Memberi saran kepada para pihak untuk menyelesaikan sengketa melalui pengadilan;

d. Menyampaikan rekomendasi atas suatu kasus pelanggaran HAM kepada pemerintah untuk ditindaklanjuti penyelesaiannya; dan

e. Menyampaikan rekomendasi atas suatu kasus pelanggaran HAM kepada Dewan Perwakilan Rakyat (DPR) untuk ditindaklanjuti.

\section{Beberapa Kasus Penyelesaian Konflik Antar Umat Beragama yang Ditangani oleh Komnas HAM}

Negara Indonesia adalah negara hukum. Pada hakikatnya manusia dianugerahkan Tuhan Yang Maha Esa hak dan kewajiban. Beberapa dekade sudah terlampaui oleh Indonesia yang mengakui kepastian HAM atas warga negaranya, namun masih saja ada masalah terkait hak dan kewajiban ini dan yang paling utama adalah hak kebebasan beragama. Provinsi Sumatera Barat sebagai bagian dari Negara Kesatuan Republik Indonesia (NKRI) sendiri, terkenal sebagai wilayah yang memiliki masyarakat yang mayoritas menganut agama Islam.

Menjaga kerukunan antar umat beragama berarti hubungan sesama umat beragama telah dilandasi rasa toleransi, saling pengertian, saling menghormati, menghargai kesetaraan dalam pengamalan ajaran agamanya, dan kerjasama dalam kehidupan bermasyarakat, berbangsa dan bernegara di dalam NKRI berdasarkan

18 Ibid. 
Pancasila dan UUD 1945. Berhubungan dengan hal tersebut, harmonisasi antara Pemerintah Sumatera Barat dan Komnas HAM Perwakilan Provinsi Sumatera Barat untuk mewujudkan kerukunan antar umat beragama dalam penegakkan dan perlindungan hak atas kebebasan beragama dan berkeyakinan sangat dibutuhkan untuk memicu upaya menciptakan suasana atas kerukunan kehidupan beragama dan berkeyakinan di Indonesia.

Menciptakan hubungan kerukunan dan kehidupan beragama dan berkeyakinan yang baik dan harmonis akan banyak mendatangkan banyak keuntungan dari berbagai macam sektor, baik itu sektor pembangunan, perekonomian, dan sektorsektor penting lainnya. Proses mengembangkan dan memajukan negara akan semakin terjaga, stabil dan terus menerus, akibat terciptanya kehidupan sosial antar warga negara yang kondusif dan aman. Tanpa terciptanya konflik yang nantinya dapat memicu permusuhan dan mengakibatkan perpecahan dari rasa kesatuan yang kuat, sudah dibangun oleh warga negara Indonesia dari sejak dulu dan tersebar dari sabang sampai merauke, dan memiliki berbagai macam suku bangsa, budaya dan bahasa.

Namun hal ini menjadi berbanding terbalik, jika kerukunan hidup umat beragama dan berkeyakinan tak mampu dijaga secara kondusif. Kerugian yang terjadi akan terasa amat besar, bukan saja kerugian ekonomi yang muncul karena akibat dari kegiatan perekonomian yang tidak berjalan dengan lancar dan berefek pada kerusakan terhadap sarana prasarana (material), tetapi juga kerugian immaterial yang tak bisa dinilai harganya, yaitu adanya kerusakan yang sangat vital akan terjadi, terhadap kerukunan umat beragama dan berkeyakinan persatuan dan kesatuan terhadap warga negara Republik Indonesia.

Kerukunan hidup umat beragama merupakan hal yang paling penting dan strategis, karena bangsa Indonesia merupakan masyarakat yang agamais. ${ }^{19}$ Pada prinsipnya setiap ajaran agama dan aliran kepercayaan diyakini selalu mengajarkan kebajikan dan kebaikan. ${ }^{20}$ Hakikat kebebasan beragama adalah pengakuan bahwa setiap orang berhak meyakini serta untuk hidup beribadat dan berkomunikasi sesuai apa yang diyakini sebagai tuntutan Tuhan yang mutlak. ${ }^{21}$ Hak kebebasan beragama di Sumatera Barat belum sepenuhnya terjamin. Dalam kehidupan bermasyarakat, tak jarang juga agama ini menjadi pemicu konflik. Itu terjadi karena masih terjadi beragam bentuk pelanggaran terkait hak atas kebebasan beragama.

\footnotetext{
19 H. Darwas, "Pedoman Kerukunan Hidup Umat Beragama Sumatera Barat", Program Peningkatan Kerukunan Hidup Umat Beragama Kantor Wilayah Departemen Agama Propinsi Sumatera Barat, Padang, 2007, hlm. 1.

20 Ibid.

${ }^{21}$ Ismail Hasani, Putusan Uji Materi Undang-Undang No./1/PNPS/1965 tentang Pencegahan Penyalahgunaan dan/atau Penodaan Agama Terhadap Undang-Undang Dasar 1945, Jakarta: Publikasi Setara Institute, 2010, hlm.19.
} 
Dari tahun 1998 sampai 2009, Komnas HAM telah menerima ratusan pengaduan terkait kasus pelanggaran hak atas kebebasan beragama dan berkeyakinan antara lain pelarangan pendirian tempat ibadat, perusakan tempat tinggal umat, pelarangan beribadat, penutupan tempat ibadat, tindakan diskriminasi terhadap umat tertentu dan penganiayaan. Kasus-kasus tersebut harus diselesaikan secara tuntas dan dicegah untuk tidak muncul kembali, sehingga tidak terjadi kerugian yang besar dalam kehidupan bernegara.

Indonesia adalah negara hukum, dimana segala sesuatunya telah dijamin baik hak maupun kewajiban. Setiap provinsi di Indonesia memiliki perwakilan Komnas HAM yang diharapkan membantu dalam hal penegakkan HAM itu sendiri. Kita mengetahui bahwa Sumatera Barat merupakan salah satu provinsi yang memiliki perwakilan Komnas HAM. Secara teoritis, UU HAM sudah menjabarkan beberapa tugas dan peranan dari Komnas HAM itu sendiri yakni pengkajian, penelitian, penyuluhan, pemantauan, dan mediasi tentang HAM.

Sejatinya, hak atas kebebasan beragama dan berkeyakinan adalah hak untuk memilih, memeluk, serta menjalankan agama dan keyakinan. Hak ini tidak dapat dikurangi dalam keadaan apapun (non-derogable rights). Adanya jaminan terhadap hak atas kebebasan beragama dan berkeyakinan terdapat pada instrumen HAM internasional dan peraturan perundang-undangan nasional. Seharusnya, agama bukanlah suatu hal yang harus dipersoalkan jika dalam kehidupan sehari-hari terjadi sinkronisasi dalam pelaksanaan hak dan kewajiban. Ketika kita membicarakan tentang hak kebebasan beragama, pasti tak terlepas dari sekelompok para penegak hak tersebut serta kewajibannya.

Pada hakikatnya, jika pemaknaan kebebasan beragama ini terjadi suatu kesalahpahaman maka suatu konflik pun akan timbul. Di Sumatera Barat, pemaknaan kebebasan beragama ini masih kurang terpahami oleh sebagian lapisan masyarakat dan pemerintah. Dimensi individual tercermin dalam perlindungan terhadap keberadaan spiritual seseorang (forum internum) termasuk di dalam dimensi ini adalah memilih-mengganti, mengadopsi, serta memeluk agama dan keyakinan. Dimensi kolektif tercermin dalam perlindungan terhadap keberadaan seseorang untuk mengeluarkan keberadaan spiritualnya dan mempertahankannya di depan publik (forum eksternum). Di Sumatera Barat terdapat beberapa temuan tentang konflik antar umat beragama akibat kurang terpahaminya makna sebenarnya hak kebebasan beragama dan berkeyakinan, diantaranya:

\section{Peraturan Gubernur Sumatera Barat Nomor 17 Tahun 2011 Tentang Larangan Kegiatan Jemaat Ahmadyah Indonesia di Provinsi Sumatera Barat}

Kebebasan beragama maupun berkeyakinan merupakan hak yang telah dijamin dalam UUD 1945 dan beberapa undang-undang lainnya. Adapun undang-undang tersebut adalah sebagai berikut: 
a. Pasal 28 I UUD 1945 menyatakan bahwa negara menjamin dan memberikan perlindungan kepada setiap warga negara untuk memeluk agama dan beribadah sesuai dengan agama dan kepercayaannya tanpa bisa dikurangi dalam keadaan apapun (non-derogable right);

b. Pasal 22 ayat (1) dan (2) UU HAM menyatakan bahwa setiap orang bebas memeluk agamanya masing-masing dan untuk beribadah menurut agama dan kepercayaannya itu dan negara menjamin kemerdekaan tiap-tiap orang memeluk agamanya masing-masing dan untuk beribadah menurut agama dan kepercayaannya itu; dan

c. Pasal 18 UU Nomor 12 Tahun 2005 tentang Ratifikasi Kovenan Internasional tentang hak-hak Sipil dan Politik (UU Ratifikasi Kovenan Hak Sipil dan Politik 2005) menyatakan bahwa hak setiap orang atas kebebasan berpikir, berkeyakinan, dan beragama serta perlindungan atas hak-hak tersebut.

Indonesia merupakan negara yang kaya dengan kemajemukan budaya, adat istiadat, suku, bahasa, agama, dan keyakinan. Di Indonesia, terdapat 5 (lima) agama dan 1 (satu) kepercayaan yang terdapat undang-undang, yaitu: Islam, Kristen Protestan, Katolik, Budha, Hindu, dan kepercayaan Konghuchu. Selain keenam agama tersebut terdapat pula beberapa keyakinan di Indonesia yaitu Ahmadyah, Bahai, Saksi Jahowa, dan lain-lain. Baik hak kebebasan beragama maupun berkeyakinan sudah dijamin dalam peraturan perundang-undangan Indonesia yaitu UUD 1945, UU HAM, UU Ratifikasi Kovenan Hak Sipil dan Politik 2005, Penetapan Presiden Republik Indonesia Nomor 1 Tahun 1965, dan Keputusan Bersama Menteri Agama dan Menteri Dalam Negeri No.01/BER/MDN-MAG/1969.

Gubernur Sumatera Barat sebagai kepala daerah, pada tanggal 24 Maret 2011 mengeluarkan Peraturan Gubernur Sumatera Barat Nomor 17 Tahun 2011 tentang Larangan Kegiatan Jemaat Ahmadyah Indonesia di Provinsi Sumatera Barat (Pergub Sumbar Larangan Ahmadyah 2011). Dalam peraturan tersebut, disebutkan dalam Pasal 3 ayat (1) bahwa penganut dan anggota pengurus jemaat Ahmadyah dilarang melakukan kegiatan dalam bentuk apapun sepanjang berkaitan dengan penyebaran penafsiran dan aktivitas yang menyimpang dari pokok-pokok ajaran agama islam. Kemudian pada pasal 3 ayat (2) dinyatakan bahwa kegiatan sebagaimana dimaksud pada ayat (1) meliputi: a) penyebaran ajaran Ahmadyah melalui lisan, tulisan ataupun melalui media elektronik; b) pemasangan papan nama organisasi jemaat Ahmadyah Indonesia di tempat umum; c) pemasangan papan nama pada rumah peribadatan, lembaga pendidikan dan lain sebagainya dengan identitas jemaat Ahmadyah Indonesia; dan d) penggunaan atribut jemaat Ahmadyah Indonesia dalam bentuk apapun.

Peraturan gubernur tersebut merupakan salah satu tindakan yang telah melanggar peraturan perundang-undangan baik UUD 1945 maupun perundang- 
undangan lain sebagaimana telah dijelaskan di atas, yang secara tegas mengakui dan menjamin kebebasan beragama dan berkeyakinan setiap orang.

Lembaga Bantuan Hukum (LBH) mengatakan bahwa Surat Ketetapan Bersama (SKB) sama sekali tidak melarang ataupun menghalang-halangi jemaat Ahmadyah untuk memeluk agama Islam dan menjalankan ibadah sesuai dengan agama dan keyakinannya dan bahwa sesungguhnya pembatasan terhadap jemaat Ahmadyah adalah semata-mata mengenai penyebaran paham atau ajaran yang menyimpang dari pokok-pokok ajaran agama Islam yaitu pengakuan adanya Nabi Muhammad SAW.

Butir 6 SKB disebutkan bahwa diperintahakan kepada aparat pemerintah daerah untuk melakukan langkah-langkah pembinaan dalam rangka pengamanan dan pengawasan pelaksanaan keputusan bersama ini. Terhadap hal ini kita dapat menyimpulkan bahwa SKB tidak pernah memerintahkan gubernur, bupati/walikota untuk membentuk peraturan tentang larangan kegiatan jemaat Ahmadyah melainkan hanya memerintahkan melakukan langkah-langkah pembinaan dalam rangka pengamanan yang semestinya harus berdasarkan hukum dan tidak bertentangan dengan peraturan perundang-undangan dan UUD 1945.

\section{SKB 2 Menteri Terkait dengan Rumah Ibadah}

Menteri Agama dan Menteri Dalam Negeri mengeluarkan SKB Nomor 01/Ber/MDNMAG/1969 tentang Pelaksanaan Tugas Aparatur Pemerintah dalam Menjamin Ketertiban dan Kelancaran Pelaksanaan Pengembangan dan Ibadat Agama oleh Pemeluknya (SKB 1/1969). Pada tanggal 21 Maret 2006, telah diterbitkan Peraturan Bersama Menteri Agama dan Menteri Dalam Negeri Nomor 9 Tahun 2006 dengan Nomor 8 Tahun 2006 tentang Pedoman Pelaksanaan Tugas Kepala Daerah/Wakil Kepala Daerah dalam Pemeliharaan Kerukunan Umat beragama dan Pendirian Rumah Ibadah. SKB 2 Menteri yang telah dikeluarkan ini membawa permasalahan dalam kehidupan beragama di beberapa kalangan sehingga menimbulkan konflik antar umat beragama.

Dalam kehidupan bermasyarakat di Sumatera Barat, tidak jarang SKB ini dijadikan alat oleh beberapa pihak untuk membatasi hak-hak para kaum minoritas. SKB dijadikan alasan bagi suatu kelompok untuk melakukan aksi penyegelan/perusakan rumah ibadah, penghalangan kegiatan ibadat, dan kekerasan terhadap jemaat. Adanya pembatasan-pembatasan dalam pendirian rumah ibadah. Hal ini terlihat dalam beberapa pasal yang terdapat dalam SKB 2 Menteri ini, yaitu:

Pasal 14:

(1) Pendirian rumah ibadat harus memenuhi persyaratan administratif dan persyaratan teknis bangunan gedung;

(2) Selain memenuhi persyaratan sebagaimana dimaksud pada ayat (1) 
pendirian rumah ibadat harus memenuhi persyaratan khusus meliputi:

a. Daftar nama dan Kartu Tanda Penduduk pengguna rumah ibadat paling sedikit 90 (sembilan puluh) orang yang disahkan oleh pejabat setempat sesuai dengan tingkat batas wilayah sebagaimana dimaksud dalam Pasal 13 ayat (3);

b. Dukungan masyarakat setempat paling sedikit 60 (enam puluh) orang yang disahkan oleh lurah/kepala desa;

c. Rekomendasi tertulis kepala kantor departemen agama kabupaten/kota; dan

d. Rekomendasi tertulis FKUB kabupaten/kota.

Dalam hal persyaratan sebagaimana dimaksud pada ayat (2) huruf a terpenuhi sedangkan persyaratan huruf $b$ belum terpenuhi, pemerintah daerah berkewajiban memfasilitasi tersedianya lokasi pembangunan rumah ibadat.

Pasal ini sudah jelas bertentangan dengan UUD 1945 Pasal 28 E dan Pasal 18 ayat (1) Kovenan Hak-Hak Sipil dan Politik. Perusakan tempat ibadah ini dilakukan oleh masyarakat dan pembakaran tempat ibadah dilakukan oleh Majelis Ulama Islam (MUI) terhadap tempat ibadah Lembaga Dakwah Islamiyah Indonesia (LDII) di Kampung Padang Panjang II oleh sekitar seratus masyarakat warga kampung Padang Panjang II pada tanggal 30 November $2010 .^{22}$

Beberapa kasus yang telah terjadi ini merupakan suatu kerawanan di bidang kerukunan hidup antar umat beragama. Kerawanan di bidang kerukunan hidup beragama pada hakikatnya adalah suatu persengketaan atau pertentangan antara dua pihak atau lebih yang disebabkan masalah-masalah keagamaan, baik intern umat beragama, antar umat beragama, maupun antar umat beragama dengan pemerintah, yang menjurus pada konflik terbuka dan dadakan-tindakan anarkis dengan ciri kekerasan fisik serta pelecehan hukum. ${ }^{23}$ Konflik-konflik yang terjadi ini mengakibatkan terganggunya stabilitas dan integritas bangsa, sehingga akan berujung pada terguncangnya persatuan dan kesatuan bangsa.

Dari beberapa kasus yang terjadi seperti disebutkan di atas, terdapat beberapa hal yang menyebabkan konflik-konflik tersebut terjadi. Beberapa temuan yang menyebabkan terjadinya konflik-konflik tersebut adalah sebagai berikut:

a. Pendirian tempat ibadah sering sekali menjadi suatu permasalahan dalam kehidupan beragama. Padahal, bila kita menyadari akan hak kebebasan beragama hal ini bukanlah suatu pemicu munculnya konflik antar umat beragama karena Pasal 28 UUD 1945 sudah menjamin hal ini;

\footnotetext{
22 Ismail Hasani dan Bonar Tigor Naipospos, Negara Menyangkal Kondisi Kebebasan Beragama/Berkeyakinan di Indonesia 2010, Jakarta: Pustaka Masyarakat Setara, 2010, hlm. 154.

$23 \mathrm{Ibid}, \mathrm{hlm} .103$.
} 
b. Penyiaran agama, baik lisan maupun tulisan, baik itu melalui media cetak, brosur, media elektronik serta media lainnya yang dapat menimbulkan konflik antar umat beragama;

c. Bantuan Luar Negeri/Lokal (daerah sendiri) untuk pengembangan dan penyebaran suatu agama, baik yang berupa bantuan materi finansial ataupun tenaga ahli kegiatan keagamaan, bila tidak mengikuti peraturan yang ada dapat menimbulkan suatu ketidakharmonisan dalam kebebasan beragama baik intern umat yang dibantu maupun antar umat beragama;

d. Perkawinan yang dilakukan oleh pasangan yang berbeda agama, walaupun pada mulanya bersifat pribadi dan konflik antar keluarga, namun hal ini dapat menyebabkan ketidakharmonisan antar umat beragama terutama pada hukum perkawinannya;

e. Penodaan agama, yakni perbuatan yang bersifat melecehkan atau menodai suatu ajaran dan keyakinan suatu agama dan kepercayaan tertentu yang dilakukan oleh seseorang atau sekelompok orang dapat menyebabkan konflik antar umat beragama;

f. Kegiatan aliran sempalan, yakni kegiatan yang dilakukan oleh seseorang atau sekelompok orang yang didasarkan pada keyakinan terhadap suatu agama tertentu secara menyimpang dari ajaran agama yang bersangkutan dan menimbulkan keresahan terhadap kehidupan beragama, dapat menyebabkan timbulnya konflik antar umat beragama;

g. Aspek-aspek non agama yang dapat mempengaruhi hak kebebasan beragama adalah kepadatan penduduk, kesenjangan sosial melalui kegiatan agama, adat istiadat atau budaya daerah yang beranekaragam, ekonomi, pelaksanaan pendidikan, gerakan separatis penyusupan ideologi dan politik berhaluan keras yang berskala lokal, regional maupun internasional yang masuk ke Indonesia/suatu daerah melalui kegiatan sosial keagamaan; dan

h. Lemahnya pengawasan dan penegakan hukum oleh pemerintah yang tengah terjadi, baik dalam pendirian rumah ibadah, penyiaran agama, bantuan luar negeri, aspek non agama yang mempengaruhi dan penodaan agama.

Dari kasus-kasus yang telah terjadi, setelah Komnas HAM Perwakilan Sumatera Barat mengumpulkan dan mengolah data yang diperoleh di lapangan terkait konflik antar umat beragama, diteruskan dengan mendengar keterangan dari saksi yang relevan serta menganalisis hasil penyelidikan atas kasus tersebut, maka kegiatan Komnas HAM selanjutnya adalah menyusun dan membuat laporan dalam bentuk laporan penyelidikan Komnas HAM Perwakilan Sumatera Barat. Setelah laporan penyelidikan selesai dikerjakan, kegiatan selanjutnya adalah penyampaian rekomendasi kewenangan Komnas HAM sesuai Pasal 89 ayat (4) huruf d UU HAM ditujukan kepada instansi terkait dengan kasus tersebut. 
Pengaduan berbagai kasus pelanggaran HAM disampaikan oleh masyarakat baik secara langsung ke Komnas HAM maupun melalui surat. Pengaduan ini akan ditangani oleh Komnas HAM tepatnya pada Sub Komisi sesuai dengan fungsinya masing-masing. Selanjutnya dilakukan penilaian apakah pengaduan tersebut merupakan pelanggaran HAM atau bukan. Pengaduan terhadap adanya pelanggaran ini dapat dilakukan baik secara langsung bertatap muka dengan Komnas HAM maupun secara tidak langsung yaitu melalui surat. Seluruh pengaduan yang diterima dianalisis secara intensif sesuai dengan ketentuan peraturan perundang-undangan yang berlaku. Berdasarkan analisis tersebut diambil tindak lanjut yang diperlukan, misalnya dengan meneruskan pengaduan tersebut kepada instansi pemerintah yang bersangkutan; mengadakan peninjauan lapangan untuk memperoleh fakta lanjutan; menyarankan diadakannya mediasi; atau jika diduga ada pelanggaran HAM yang berat, mengusulkan pembentukan tim ad hoc penyelidikan berdasarkan UU Pengadilan HAM. ${ }^{24}$

\section{Penutup}

Komnas HAM merupakan suatu lembaga mandiri yang kedudukannya setingkat dengan lembaga negara lainnya yang berfungsi melaksanakan pengkajian, penelitian, penyuluhan, pemantauan, dan mediasi HAM yang dalam hal ini adalah melaksanakan peranannya dalam penyelesaian konflik antar umat beragama. Komnas HAM juga mempunyai subpoena power dalam membantu penyelesaian konflik antar umat beragama ataupun yang berkaitan dengan hak kebebasan beragama. Sesuai dengan amanat UU HAM, Komnas HAM mempunyai fungsi pengkajian dan penelitian, penyuluhan, pemantauan, serta mediasi. Adapun peraturan yang dapat digunakan dalam penyelesaian konflik antar umat beragama oleh Komnas HAM antara lain, Peraturan Gubernur Sumatera Barat Nomor 17 Tahun 2011 tentang Larangan Kegiatan Jemaat Ahmadyah Indonesia di Provinsi Sumatera Barat dan SKB 2 Menteri terkait dengan Rumah Ibadah. Dapat disimpulkan bahwa Komnas HAM kurang tanggap dalam melihat berbagai konflik antar umat beragama yang ada di Sumatera Barat akibat minimnya melakukan peninjauan dan mediasi ke daerah konflik. Amanat dari UU HAM menyatakan bahwa Komnas HAM merupakan salah satu lembaga yang dibentuk untuk menjamin hak kebebasan beragama.

Dari pembahasan serta uraian penelitian di atas dan demi terwujudnya penegakkan dan perlindungan hak kebebasan beragama serta untuk menghindari konflik-konflik antar umat beragama harus ada upaya sungguh-sungguh baik dari

\footnotetext{
24 Pelangaran HAM yang berat ini dibagi menjadi tiga yaitu: a) tidak dapat dibuktikan kebenarannya; b) belum dapat dibuktikan kebenarannya; dan c) dapat dibuktikan kebenaranya.
} 
pemerintah, Komnas HAM dan pihak-pihak terkait mempertegas peranan mereka masing-masing. Perlunya sikap yang konsekuen yang harus menjadi prinsip Komnas HAM dalam melaksanakan peranannya sebagai institusi atau lembaga negara serta tetap pada sikap independensi sesuai yang diamanahkan oleh UU HAM itu sendiri, dalam memberikan rekomendasi dan menangani setiap kasus yang terindikasi sebagai pelanggaran HAM. Selain itu, pemerintah wajib mendorong masyarakat untuk mendukung upaya pemenuhan hak atas kebebasan beragama dan berkeyakinan. Peran dari LSM, akademisi, tokoh agama, tokoh masyarakat dan stake holders lainnya juga penting. Sinergi dari pemerintah dengan para stake holders hak atas kebebasan beragama dan berkeyakinan sangat dibutuhkan untuk memantik upaya penciptaan kerukunan kehidupan beragama dan berkeyakinan di Indonesia. Apabila Indonesia mampu menciptakan kerukunan kehidupan beragama dan berkeyakinan maka hal itu akan mendatangkan banyak keuntungan seperti Indonesia akan lebih mudah menyerap investasi untuk pembangunan, perekonomian akan terjaga dan stabil, serta kehidupan sosial akan lebih aman dan terjaga.

\section{Daftar Pustaka}

\section{Buku}

Eddie Riyadi (et.al.), Kebenaran Versus Keadilan, Elsam, Jakarta, 2003.

Erick J. Barus, Kebebasan Beragama, HAM dan Komitmen Kebangsaan, Bidang Marturia-PGI, Jakarta, 2009.

Evans, William M., The Sociology of Law A Social-Structural Perspective, Free Press, A Division of Macwiliam Publishing, New York, University of Pennsylvania.

Institusi Nasional Hak Asasi Manusia, Seri Pelatihan Profesional No. 4, Perserikatan Bangsa-Bangsa.

Ismail Hasani dan Bonar Tigor Naipospos, Negara Menyangkal Kondisi Kebebasan Beragama/Berkeyakinan di Indonesia 2010, Pustaka Masyarakat Setara, Jakarta, 2010.

Ismail Hasani, Putusan Uji Materi Undang-Undang No./1/PNPS/1965 tentang Pencegahan Penyalahgunaan dan/atau Penodaan Agama Terhadap UndangUndang Dasar 1945, Publikasi Setara Institute, Jakarta, 2010.

Kumanto Sunarto, Pengantar Sosiologi, Fakultas Ekonomi Universitas Indonesia, Jakarta, 1993.

Komisi Nasional Hak Asasi Manusia, Laporan Tahunan Komisi Nasional Hak Asasi Manusia Indonesia, Komnas HAM, Jakarta, 2004. 
Suryadi Radjab, Indonesia:Hilangnya Rasa Aman. Hak Asasi Manusia dan Transisi Politik Indonesia, Perhimpunan Bantuan Hukum dan Hak Asasi Manusia Indonesia dan The Asia Foundation, Jakarta, 2002.

Soerjono Soekanto, Sosiologi Suatu Pengantar, Raja Grafindo Persada, Jakarta, 2006.

\section{Dokumen Lain}

H. Darwas, "Pedoman Kerukunan Hidup Umat Beragama Sumatera Barat”, Program Peningkatan Kerukunan Hidup Umat Beragama Kantor Wilayah Departemen Agama Provinsi Sumatera Barat, Padang, 2007.

Sudarto, "Kebebasan Agama dalam Cita dan Realita", Makalah Hasil Pemantauan Sekaligus Pengalaman Langsung dari Lembaga PUSAKA Padang, Padang, 2011.

\section{Dokumen Hukum}

Undang-Undang Negara Kesatuan Republik Indonesia Tahun 1945.

Undang-Undang Republik Indonesia Nomor 39 Tahun 1999 tentang Hak Asasi Manusia.

Keputusan Presiden Nomor 50 Tahun 1993 tentang Pembentukan Komisi Nasional Hak Asasi Manusia.

Deklarasi Universal Hak Asasi Manusia 1948. 